\title{
Angiogenesis - still a worthwhile target for breast cancer therapy?
}

Simon Lord and Adrian L Harris*

\section{Introduction}

Tumour angiogenesis was identified as a target for cancer therapy in the 1970s. To date, one anti-angiogenesis treatment, bevacizumab, which targets the vascular endothelial growth factor (VEGF) signalling pathway, has been licensed for the treatment of advanced breast cancer. However, in clinical studies only modest improvements in progression-free survival have been seen for anti-angiogenic treatment of this disease (Table 1). Many patients have no response to these drugs at all, and often after an initial response patients soon relapse. Indeed, the US Food and Drug Administration (FDA) Oncologic Drugs Advisory Committee (ODAC) recently voted almost unanimously to remove the treatment of advanced breast cancer as a licensed indication for bevacizumab. Results from trials in the adjuvant and neoadjuvant setting for breast cancer are still awaited. We discuss why anti-angiogenesis therapies have not lived up to their early expectations and how new strategies for their use may lead to their greater effectiveness.

\section{Mechanisms of resistance to anti-angiogenic therapy}

Several mechanisms for intrinsic and acquired tumour resistance to anti-angiogenic therapy have now been proposed. It is now clear that revascularisation can occur after the inhibition of VEGF signalling due to the upregulation of alternative angiogenic signalling pathways. This was first revealed in a mouse model of pancreatic neuroendocrine cancer treated with the antiVEGF receptor (VEGFR) monoclonal antibody DC101; in this model an initial response was followed by tumour regrowth and revascularisation. This was associated with higher levels of mRNAs for the pro-angiogenic factors fibroblast growth factor 1 and 2, Ephrin A1 and A2 (Efna1 and Efna2) and Angiopoietin 1 (Angpt1) [1]. Further in vivo studies have suggested the importance of

*Correspondence: aharris.lab@imm.ox.ac.uk

Molecular Oncology Laboratories, University Department of Medical Oncology, Weatherall Institute of Molecular Medicine, John Radcliffe Hospital, Headington, Oxford OX3 9DS, UK the promotion of a multitude of pro-angiogenic factors in response to anti-angiogenic therapy, including interleukin-8, VEGF, platelet derived growth factor (PDGF)A and placental growth factor [2-4].

Another angiogenic pathway, Delta-like ligand-4 (DLL4)-Notch signalling, is induced by VEGF and acts as a counterbalance to VEGF upregulation by inhibiting angiogenesis. Inhibition of DLL4-Notch signalling leads to an increase in blood vessel density, intratumoural hypoxia and the induction of pro-angiogenic factors. Preclinical studies have suggested that tumours that are resistant to anti-VEGF therapy are susceptible to blockade of DLL4-Notch signalling due to the promotion of non-productive angiogenesis $[5,6]$.

Pericytes, the periendothelial support cells of the microvascular structure, also seem to play an important role in treatment resistance. It has been observed that even after tumour devascularisation in response to VEGF inhibition, vessels remain that are heavily covered with pericytes. Furthermore, those vessels that do not have this 'pericyte scaffold' are more susceptible to VEGF inhibition. Lastly, pericytes have the ability to release pro-angiogenic factors in response to PDGF. Hence, one strategy to overcome this 'pericyte resistance' mechanism may be to use PDGFR inhibitors to dissociate pericytes from the endothelium. However, some studies suggest that a lack of pericyte endothelial coverage may promote metastasis due to a loss of endothelial integrity [7-9].

Several single nucleotide VEGF polymorphisms have been described that may be involved in anti-angiogenic treatment resistance. It is likely that only a few of these polymorphisms have an effect on protein expression and some polymorphisms may in fact predict positively for response to anti-angiogenic therapy.

Anti-angiogenic treatment almost certainly leads to intratumoural hypoxia and subsequent induction of the hypoxia inducible factor (HIF)-1 pathway [10]. Thus, the treatment may rapidly activate a key transcription factor that induces angiogenesis. HIF activation has been correlated with poor prognosis in a variety of solid tumours. A clinical study has demonstrated that elevated carbonic anhydrase 9 (encoded by CA9, a HIF-1 target gene) is associated with both poor prognosis and poor 
Table 1. Phase 3 trial results, to date, of anti-angiogenic agents in the treatment of advanced breast cancer

\begin{tabular}{|c|c|c|c|c|}
\hline Trial name and design & $\begin{array}{l}\text { Treatment } \\
\text { type }\end{array}$ & $\begin{array}{l}\text { Progression free } \\
\text { survival (months) }\end{array}$ & Overall survival (months) ${ }^{\mathrm{a}}$ & Response rate ${ }^{a}$ \\
\hline Capecitabine \pm bevacizumab & Refractory & $\begin{array}{l}4.86 \text { versus } 4.17 \\
(H R 0.98 ; P=0.857)\end{array}$ & 15.1 versus 14.5 & $\begin{array}{l}19.8 \% \text { versus } 9.1 \% \\
\quad(P=0.001)\end{array}$ \\
\hline $\begin{array}{l}\text { RIBBON-2: second line } \\
\text { chemotherapy } \pm \text { bevacizumab }\end{array}$ & Second line & $\begin{array}{c}7.2 \text { versus } 5.1 \\
\text { (HR } 0.775 ; P=0.0072)\end{array}$ & $\begin{array}{l}18.0 \text { versus } 16.4 \\
\quad(P=0.372)\end{array}$ & $\begin{array}{l}39.5 \% \text { versus } 29.6 \% \\
\quad(P=0.0193)\end{array}$ \\
\hline E2100: paclitaxel \pm bevacizumab & First line & $\begin{array}{c}11.8 \text { versus } 5.9 \\
(\operatorname{HR} 0.60 ; P=<0.001)\end{array}$ & $\begin{array}{l}26.7 \text { versus } 25.2 \\
(\mathrm{HR} 0.88 ; P=0.16)\end{array}$ & $\begin{array}{l}36.9 \% \text { versus } 21.2 \% \\
(P<0.001)\end{array}$ \\
\hline AVADO: docetaxel \pm bevacizumab & First line & $\begin{array}{c}8.8 \text { versus } 8.0 \\
(\operatorname{HR} 0.61 ; P=0.0001)\end{array}$ & Not published & $\begin{array}{l}44.4 \% \text { versus } 63.1 \% \\
\quad(P=0.0001)\end{array}$ \\
\hline $\begin{array}{l}\text { RIBBON-1: capecitabine }(\mathrm{C}) \text { or } \\
\text { taxane }(\mathrm{T}) \text { or anthracycline }(\mathrm{A}) \pm \\
\text { bevacizumab or placebo }\end{array}$ & First line & $\begin{array}{c}C: 8.6 \text { versus } 5.7 \\
(H R 0.688 ; P=0.0002) \\
A+T \text { b: } 9.2 \text { versus } 8.0 \\
(H R 0.644 ; P \leq 0.0001)\end{array}$ & $\begin{array}{c}\text { C: } 29.0 \text { versus } 21.2 \\
(H R 0.847 ; P=0.2706) \\
A+T^{b}: 25.2 \text { versus } 23.8 \\
(H R 1.032 ; P=0.8298)\end{array}$ & $\begin{array}{c}C: 35.4 \% \text { versus } 23.6 \% \\
(P=0.0097) \\
A+T^{b}: 51.3 \% \text { versus } 37.9 \% \\
(P=0.0054)\end{array}$ \\
\hline Capecitabine \pm sunitinib & Refractory & $\begin{array}{l}5.5 \text { versus } 5.9 \\
(\text { HR } 1.224)\end{array}$ & $\begin{array}{l}16.4 \text { versus } 16.5 \\
\quad(H R 0.995)\end{array}$ & $18.6 \%$ versus $16.3 \%$ \\
\hline Capecitabine versus sunitinib & Refractory & $\begin{array}{c}2.8 \text { versus } 4.2 \\
\text { (HR } 1.473 ; P<0.001)\end{array}$ & Not published & $9.1 \%$ versus $12.9 \%$ \\
\hline Docetaxel \pm sunitinib & First line & $\begin{array}{l}8.6 \text { versus } 8.3 \\
(\text { HR } 0.922)\end{array}$ & $\begin{array}{l}24.8 \text { versus } 25.5 \\
\quad(H R 1.207)\end{array}$ & $\begin{array}{l}51 \% \text { versus } 39 \% \\
\quad(P=0.0018)\end{array}$ \\
\hline
\end{tabular}

${ }^{\mathrm{a}}$ Anti-angiogenic treatment group first. ${ }^{\mathrm{b}} \mathrm{Anthracycline}$ and taxane cohorts analysed as a pooled group. HR, hazard ratio.

response to irinotecan and bevacizumab for malignant astrocytoma [11-13]. Hypoxia leads to the recruitment of bone marrow derived cells, such as tumour-associated macrophages and pro-angiogenic monocytic cells, including CD11b+ myeloid cells, VEGFR1+ haemangiocytes and TIE2+ monocytes. In a mouse glioblastoma model, their recruitment to the tumour microenvironment has been associated with HIF-1 activation and subsequent tumour progression and angiogenesis [14]. These inflammatory cells are associated with tumour progression and refractoriness to anti-VEGF therapy in mouse models [15]. It has also been shown that HIF-1 in a pancreatic cancer model increases expression of c-MET and secretion of hepatocyte growth factor, both of which are associated with poor prognosis, metastasis and angiogenesis in solid tumours [16-18].

Metabolic reprogramming of the cancer cell by HIF-1, to aid the switch from aerobic to anaerobic metabolism, involves the activation of key metabolic enzymes, including lactate dehydrogenase A and pyruvate dehydrogense $1[19,20]$. HIF-1 has also been associated with the upregulation of the glucose transporter GLUT1 and reduced mitochondrial mass due to upregulation of the BNIP3 gene $[21,22]$. Evidence is growing that lipid metabolism is significantly altered under hypoxic conditions and that this is, at least in part, regulated by the HIF axis [23]. These profound changes in cancer metabolism are likely to play a significant role in resistance to antiangiogenic therapy, and the development of drugs that exploit these changes in cancer metabolism may well give rise to synergistic combination with anti-angiogenic treatments.

\section{Are we treating the wrong patients?}

Early studies of anti-angiogenic agents predominantly assessed their use as a single agent therapy and in heavily pretreated patients. However, phase 3 trial data have predominantly demonstrated benefit in terms of progression-free survival for anti-angiogenic treatment in advanced breast cancer for patients that have received only minimal prior treatment and when therapy is given in combination with chemotherapy (Table 1). Late stage breast cancers express many different angiogenic factors, such as fibroblast growth factor 2, in contrast to early stage breast cancers, which predominantly express VEGF [24]. Hence, it may be that heavily pretreated tumours have angiogenesis resistance pathways that have already become activated. It is also hypothesised that the associated normalisation of tumour vasculature with antiangiogenic therapy results in improved delivery of chemotherapy and hence efficacy.

The selection of patients on the basis of biomarkers associated with intrinsic tumour resistance is a key strategy to improve the likelihood of clinical benefit. So far every phase 3 trial of anti-angiogenic treatments has been undertaken in essentially unselected patients with little effort made to assess for biomarkers of response or resistance. This is in contrast to other highly targeted agents, in particular trastuzumab or anti-epidermal growth factor receptor (EGFR) therapy.

Several surrogate markers for anti-angiogenesis are under investigation to predict response. Microvessel density is one such marker, which can be assessed after staining specific to an endothelial cell-specific marker, such as CD31, CD34 or CD105. However, this has not as 
yet yielded useful data, probably because it does not assess functional vessels. It is thought that highly vascularised tumours are more susceptible to antiangiogenesis therapy, although some preclinical studies have suggested that less well vascularised tumours may also respond well [25]. Tumour vascular function in terms of patency and 'blood vessel leakiness' can also be assessed using the fluorescent dye Hoescht 33342 and high molecular weight tracers (for example, fluorescencelabelled dextran), respectively $[8,26]$. Thus far, most of these markers have predominantly been assessed in preclinical studies alone.

The phase 3 E2100 study that examined combination treatment with paclitaxel and bevacizumab versus paclitaxel alone in advanced breast cancer demonstrated that the VEGF-2578 AA genotype was associated with a superior median overall survival. However, to be of value this needs confirmation in other studies and other tumour types, with much more extensive validation. Plasma levels of VEGF and vascular cell adhesion molecule 1 did not correlate with clinical outcome and so far neither are of value [27].

Several studies have investigated the predictive potential of circulating endothelial cells and circulating tumour cells in patients with advanced breast cancer receiving combination treatment with bevacizumab. Higher levels of circulating endothelial cells at baseline have consistently correlated with prolonged clinical benefit [28-31]. At least one study has also shown that an increase in circulating endothelial cells during treatment is associated with improved time to progression [28]. Baseline circulating tumour cell positivity has been shown to negatively predict clinical outcome, although changes during treatment have not been shown to be significant [28]. Development of viable assays for these markers may allow for their routine use in the clinical setting in the near future.

Real-time monitoring of tumour response and alterations in vascularity using non-invasive imaging techniques are the most likely approach to succeed in the targeting of treatment. Positron emission tomographycomputed tomography (PET-CT) and single photon emission computed tomography (SPECT) tracers linked to VEGF or VEGFR antibodies are being developed. Contrast enhanced ultrasound is also being assessed as a tool to characterise tumour angiogenesis [32]. Dynamic contrast enhanced MRI is a promising imaging modality that has been used as a biomarker of efficacy in clinical trials of anti-angiogenesis inhibitors. The main biomarker used in these studies has been the measurement of the volume transfer coefficient of a contrast agent across the capillary wall $\left(K^{\text {trans }}\right)$ and changes in $K^{\text {trans }}$ have been shown to independently predict prognosis for patients with high grade gliomas [33]. In a small study, patients with advanced breast cancer treated with bevacizumab had significant reductions in $\mathrm{K}^{\text {trans }}$ from baseline, although this did not predict response [34]. However, the variables obtained from dynamic contrast enhanced MRI (DCE-MRI) are highly dependent on the data acquisition and image analysis methods used. Hence, reproducibility has been problematic and clinical adoption outside of the research setting has been slow [35].

\section{Conclusion}

Anti-VEGF therapy clearly affects the growth of breast cancer, and new targets for anti-angiogensis therapy continue to be discovered. Combination treatment may deliver greater benefit by circumventing resistance mechanisms. This particularly relates to the use of drugs that target the hypoxia-induced pathways - for example, met and carbonic anhydrase 9. Clinical research, especially in phase 3 , needs to place a greater emphasis on the discovery of biomarkers that allow clinicians to select patients that are likely to gain significant benefit from treatment. This can be achieved through 'window of opportunity' studies in which anti-angiogenesis agents are given in a neoadjuvant setting, allowing their study in isolation. The development of standardization for imaging techniques is also likely to improve the targeting of these treatments. Thus, the development of highly specific drugs needs to be matched by the development of biomarkers for response. In general, current trials have omitted the many opportunities to develop these, ultimately depriving patients who may respond of therapy because the cost-effectiveness of treating allcomers is too low.

\section{Abbreviations}

DLL, Delta-like ligand; EGFR, epidermal growth factor receptor; HIF, hypoxia inducible factor; MRI, magnetic resonance imaging; PDGF, platelet derived growth factor; VEGF, vascular endothelial growth factor; VEGFR, vascular endothelial growth factor receptor.

\section{Competing interests}

The authors declare that they have no competing interests.

\section{Acknowledgements}

This article has been published as part of Breast Cancer Research Volume 12 Supplement 4, 2010: Controversies in Breast Cancer 2010. The full contents of the supplement are available online at http://breast-cancer-research.com/ supplements/12/S4

\section{Published: 20 December 2010}

\section{References}

1. Casanovas O, Hicklin DJ, Bergers G, Hanahan D: Drug resistance by evasion of antiangiogenic targeting of VEGF signaling in late-stage pancreatic islet tumors. Cancer Cell 2005, 8:299-309.

2. Mizukami Y, Jo WS, Duerr EM, Gala M, Li J, Zhang X, Zimmer MA, Iliopoulos O, Zukerberg LR, Kohgo Y, Lynch MP, Rueda BR, Chung DC: Induction of interleukin-8 preserves the angiogenic response in HIF-1alpha-deficient colon cancer cells. Nat Med 2005, 11:992-997.

3. Fernando NT, Koch M, Rothrock C, Gollogly LK, D'Amore PA, Ryeom S, Yoon SS: Tumor escape from endogenous, extracellular matrix-associated angiogenesis inhibitors by up-regulation of multiple proangiogenic 
factors. Clin Cancer Res 2008, 14:1529-1539.

4. Fischer C, Jonckx B, Mazzone M, Zacchigna S, Loges S, Pattarini L, Chorianopoulos E, Liesenborghs L, Koch M, De Mol M, Autiero M, Wyns S, Plaisance S, Moons L, van Rooijen N, Giacca M, Stassen JM, Dewerchin M, Collen D, Carmeliet P: Anti-PIGF inhibits growth of VEGF(R)-inhibitorresistant tumors without affecting healthy vessels. Cell 2007, 131:463-475.

5. Ridgway J, Zhang G, Wu Y, Stawicki S, Liang WC, Chanthery Y, Kowalski J, Watts RJ, Callahan C, Kasman I, Singh M, Chien M, Tan C, Hongo JA, de Sauvage F, Plowman G, Yan M: Inhibition of DII4 signalling inhibits tumour growth by deregulating angiogenesis. Nature 2006, 444:1083-1087.

6. Noguera-Troise I, Daly C, Papadopoulos NJ, Coetzee S, Boland P, Gale NW, Lin $H C$, Yancopoulos GD, Thurston G: Blockade of DII4 inhibits tumour growth by promoting non-productive angiogenesis. Nature 2006, 444:1032-1037.

7. Yonenaga Y, Mori A, Onodera H, Yasuda S, Oe H, Fujimoto A, Tachibana T, Imamura M: Absence of smooth muscle actin-positive pericyte coverage of tumor vessels correlates with hematogenous metastasis and prognosis of colorectal cancer patients. Oncology 2005, 69:159-166.

8. Xian X, Håkansson J, Ståhlberg A, Lindblom P, Betsholtz C, Gerhardt H, Semb H: Pericytes limit tumor cell metastasis. J Clin Invest 2006, 116:642-651.

9. Welen K, Jennbacken K, Tesan T, Damber JE: Pericyte coverage decreases invasion of tumour cells into blood vessels in prostate cancer xenografts. Prostate Cancer Prostatic Dis 2009, 12:41-46.

10. Pàez-Ribes M, Allen E, Hudock J, Takeda T, Okuyama H, Viñals F, Inoue M, Bergers G, Hanahan D, Casanovas O: Antiangiogenic therapy elicits malignant progression of tumors to increased local invasion and distant metastasis. Cancer Cell 2009, 15:220-231.

11. Sathornsumetee S, Cao Y, Marcello JE, Herndon JE 2nd, McLendon RE, Desjardins A, Friedman HS, Dewhirst MW, Vredenburgh JJ, Rich JN: Tumor angiogenic and hypoxic profiles predict radiographic response and survival in malignant astrocytoma patients treated with bevacizumab and irinotecan. J Clin Oncol 2008, 26:271-278.

12. Zhong H, De Marzo AM, Laughner E, Lim M, Hilton DA, Zagzag D, Buechler P, Isaacs WB, Semenza GL, Simons JW: Overexpression of hypoxia-inducible factor 1alpha in common human cancers and their metastases. Cancer Res 1999, 59:5830-5835

13. Talks KL, Turley H, Gatter KC, Maxwell PH, Pugh CW, Ratcliffe PJ, Harris AL: The expression and distribution of the hypoxia-inducible factors HIF-1alpha and HIF-2alpha in normal human tissues, cancers, and tumor-associated macrophages. Am J Pathol 2000, 157:411-421.

14. De Palma M, Venneri MA, Galli R, Sergi Sergi L, Politi LS, Sampaolesi M, Naldini $L:$ Tie2 identifies a hematopoietic lineage of proangiogenic monocytes required for tumor vessel formation and a mesenchymal population of pericyte progenitors. Cancer Cell 2005, 8:211-226

15. Shojaei F, Wu X, Qu X, Kowanetz M, Yu L, Tan M, Meng YG, Ferrara N: G-CSFinitiated myeloid cell mobilization and angiogenesis mediate tumor refractoriness to anti-VEGF therapy in mouse models. Proc Natl Acad Sci USA 2009, 106:6742-6747.

16. Wojta J, Kaun C, Breuss JM, Koshelnick Y, Beckmann R, Hattey E, Mildner M, Weninger W, Nakamura T, Tschachler E, Binder BR: Hepatocyte growth factor increases expression of vascular endothelial growth factor and plasminogen activator inhibitor-1 in human keratinocytes and the vascular endothelial growth factor receptor flk-1 in human endothelial cells. Lab Invest 1999, 79:427-438.

17. Zhang YW, Su Y, Volpert OV, Vande Woude GF: Hepatocyte growth factor/ scatter factor mediates angiogenesis through positive VEGF and negative thrombospondin 1 regulation. Proc Natl Acad Sci U S A 2003, 100:12718-12723

18. Ide T, Kitajima Y, Miyoshi A, Ohtsuka T, Mitsuno M, Ohtaka K, Koga Y, Miyazaki $K$ : Tumor-stromal cell interaction under hypoxia increases the invasiveness of pancreatic cancer cells through the hepatocyte growth factor/c-Met pathway. Int J Cancer 2006, 119:2750-2759.

19. Semenza GL, Jiang BH, Leung SW, Passantino R, Concordet JP, Maire $P$, Giallongo A: Hypoxia response elements in the aldolase A, enolase 1, and lactate dehydrogenase A gene promoters contain essential binding sites for hypoxia-inducible factor 1. J Biol Chem 1996, 271:32529-32537.

20. Papandreou I, Cairns RA, Fontana L, Lim AL, Denko NC: HIF-1 mediates adaptation to hypoxia by actively downregulating mitochondrial oxygen consumption. Cell Metab 2006, 3:187-197.

21. Ebert BL, Firth JD, Ratcliffe PJ: Hypoxia and mitochondrial inhibitors regulate expression of glucose transporter-1 via distinct Cis-acting sequences. J Biol Chem 1995, 270:29083-29089.

22. Zhang H, Bosch-Marce M, Shimoda LA, Tan YS, Baek JH, Wesley JB, Gonzalez FJ, Semenza GL: Mitochondrial autophagy is an HIF-1-dependent adaptive metabolic response to hypoxia. J Biol Chem 2008, 283:10892-10903.

23. Rankin EB, Rha J, Selak MA, Unger TL, Keith B, Liu Q, Haase VH: Hypoxiainducible factor 2 regulates hepatic lipid metabolism. Mol Cell Biol 2009, 29:4527-4538

24. Relf M, LeJeune S, Scott PA, Fox S, Smith K, Leek R, Moghaddam A, Whitehouse R, Bicknell R, Harris AL: Expression of the angiogenic factors vascular endothelial cell growth factor, acidic and basic fibroblast growth factor, tumor growth factor beta-1, platelet-derived endothelial cell growth factor, placenta growth factor, and pleiotrophin in human primary breast cancer and its relation to angiogenesis. Cancer Res 1997, 57:963-969.

25. Beecken WD, Fernandez A, Joussen AM, Achilles EG, Flynn E, Lo KM, Gillies SD, Javaherian K, Folkman J, Shing Y: Effect of antiangiogenic therapy on slowly growing, poorly vascularized tumors in mice. J Natl Cancer Inst 2001, 93:382-387.

26. Wildiers H, Guetens $G$, De Boeck G, Verbeken E, Landuyt B, Landuyt W, de Bruijn EA, van Oosterom AT: Effect of antivascular endothelial growth factor treatment on the intratumoral uptake of CPT-11. Br J Cancer 2003, 88:1979-1986.

27. Schneider BP, Wang M, Radovich M, Sledge GW, Badve S, Thor A, Flockhart DA, Hancock B, Davidson N, Gralow J, Dickler M, Perez EA, Cobleigh M, Shenkier T, Edgerton S, Miller KD; ECOG 2100: Association of vascular endothelial growth factor and vascular endothelial growth factor receptor-2 genetic polymorphisms with outcome in a trial of paclitaxel compared with paclitaxel plus bevacizumab in advanced breast cancer: ECOG 2100. J Clin Oncol 2008, 26:4672-4678.

28. Bidard FC, Mathiot C, Degeorges A, Etienne-Grimaldi MC, Delva R, Pivot X, Veyret C, Bergougnoux L, de Cremoux P, Milano G, Pierga JY: Clinical value of circulating endothelial cells and circulating tumor cells in metastatic breast cancer patients treated first line with bevacizumab and chemotherapy. Ann Oncol 2010, 21:1765-1771.

29. Torrisi R, Bagnardi V, Cardillo A, Bertolini F, Scarano E, Orlando L, Mancuso P, Luini A, Calleri A, Viale G, Goldhirsch A, Colleoni M: Preoperative bevacizumab combined with letrozole and chemotherapy in locally advanced ER- and/or PgR-positive breast cancer: clinical and biological activity. Br J Cancer 2008, 99:1564-1571.

30. Dellapasqua S, Bertolini F, Bagnardi V, Campagnoli E, Scarano E, Torrisi R, Shaked Y, Mancuso P, Goldhirsch A, Rocca A, Pietri E, Colleoni M: Metronomic cyclophosphamide and capecitabine combined with bevacizumab in advanced breast cancer. J Clin Oncol 2008, 26:4899-4905.

31. Calleri A, Bono A, Bagnardi V, Quarna J, Mancuso P, Rabascio C, Dellapasqua S, Campagnoli E, Shaked Y, Goldhirsch A, Colleoni M, Bertolini F: Predictive potential of angiogenic growth factors and circulating endothelial cells in breast cancer patients receiving metronomic chemotherapy plus bevacizumab. Clin Cancer Res 2009, 15:7652-7657.

32. Willmann JK, Kimura RH, Deshpande N, Lutz AM, Cochran JR, Gambhir SS: Targeted contrast-enhanced ultrasound imaging of tumor angiogenesis with contrast microbubbles conjugated to integrin-binding knottin peptides. J Nucl Med 2010, 51:433-440.

33. Mills SJ, Patankar TA, Haroon HA, Baleriaux D, Swindell R, Jackson A: Do cerebral blood volume and contrast transfer coefficient predict prognosis in human glioma? AJNR Am J Neuroradiol 2006, 27:853-858.

34. Wedam SB, Low JA, Yang SX, Chow CK, Choyke P, Danforth D, Hewitt SM Berman A, Steinberg SM, Liewehr DJ, Plehn J, Doshi A, Thomasson D, McCarthy N, Koeppen H, Sherman M, Zujewski J, Camphausen K, Chen H, Swain SM: Antiangiogenic and antitumor effects of bevacizumab in patients with inflammatory and locally advanced breast cancer. J Clin Oncol 2006, 24:769-777.

35. O'Connor JP, Jackson A, Parker GJ, Jayson GC: DCE-MRI biomarkers in the clinical evaluation of antiangiogenic and vascular disrupting agents. Br J Cancer 2007, 96:189-195.

doi:10.1186/bcr2748

Cite this article as: Lord S, Harris AL: Angiogenesis - still a worthwhile target for breast cancer therapy? Breast Cancer Research 2010, 12(Suppl 4):S19. 